Branimir N. Grgur*, Lazar Marunkić

University of Belgrade, Faculty of Technology and Metallurgy, Belgrade, Serbia
Scientific paper

ISSN 0351-9465, E-ISSN 2466-2585

UDC: 620.193 .4

doi: $10.5937 /$ ZasMat1802243G

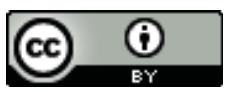

Zastita Materijala 59 (2)

243 - 248 (2018)

\title{
The influence of chloride anions on the pitting corrosion of aluminum alloy EN 46000
}

\begin{abstract}
The corrosion behavior of AlSigCu3 aluminum alloy, which is commonly used for manufacturing radiators of remote central heating systems, is investigated. The tendency for pitting corrosion is investigated in the phosphate buffer solution at $\mathrm{pH}=7$, in the sodium chloride anion concentration range 10-300 $\mathrm{mg} \mathrm{dm}^{-3}$. The critical pitting potentials are estimated. The behavior of aluminum alloy and copper corrosion couple is also investigated.
\end{abstract}

Keywords: Corrosion, Central heating systems, Radiators, Critical potential

\section{INTRODUCTION}

In the modern remote central heating systems in the past twenty years, the use of the aluminum alloys based radiators practically replaced the old ones based on cast iron. Today, the most commonly used aluminum alloys for radiator manufacturing are based on $\mathrm{AISi9}(11) \mathrm{Cu} 3(2)(\mathrm{Fe})$ alloy (EN 46000 and EN46100), due excellent mechanical, thermic and corrosion properties. Aluminumsilicon castings constitute $85 \%$ to $90 \%$ of the total aluminum-cast parts produced; aluminum alloys containing silicon as the major alloying element offer excellent castability, good corrosion resistance, and can be machined and welded [1,2]. Corrosion of these alloys is practically suppressed in the $\mathrm{pH}$ range of 6 to 8 in the de-aerated and low chloride containing water [3]. Nevertheless, in the open to air solutions containing halide ions, with $\mathrm{Cl}^{-}$ being the most common, aluminum alloys are susceptible to pitting corrosion [4]. This process occurs, because in the presence of oxygen, the metal is readily polarized to its pitting potential and because chlorides contribute to the formation of soluble chlorinated aluminum(hydro)oxide which

Corresponding author: Branimir N. Grgur

E-mail: BNGrgur@tmf.bg.ac.rs

Paper received: 19. 03. 2018.

Paper accepted: 24. 04. 2018.

Paper is available on the website: www.idk.org.rs/journal interferes with the formation of a stable, protective, oxide on the aluminum surface [5-7].

In these days, the most commonly used piping, especially in buildings, are made from copper. Copper in contact with the aluminum alloys act as a cathode and can polarized anode significantly, in some cases to the critical pitting potentials. In the presence of chloride, with limiting concentrations of $<300 \mathrm{mg} \mathrm{dm}^{-3}$ [8].

Therefore, in this paper, we investigated the influence of chloride ion concentrations on the corrosion behavior of aluminum alloy AISi9Cu3(Fe) - EN 46000 alloy.

\section{EXPERIMENTAL}

The chemical composition of the used aluminum alloy according to the European norm EN 1706 [9] is shown in Table 1.

Electrodes made from aluminum alloy plate with dimensions of $2 \mathrm{~cm} \times 10 \mathrm{~cm}$ and exposed area of $5 \mathrm{~cm}^{2}$ are used. Before experiments, the electrode is mechanically grinded with fine sandpaper and degreased in acetone. Electrochemical glass cell, with the volume of $200 \mathrm{~cm}^{3}$, equipped with reference and counter electrode compartments is used. Saturated calomel and platinum mesh are used as reference and counter electrode respectively. As a corrosion medium, the phosphate buffer with $\mathrm{pH}=7.0$ (commonly used in the conditioning of the $\mathrm{pH}$ of the circulating water) 
is used, with the following composition: $6,81 \mathrm{~g} \mathrm{dm}^{-3}$ $\mathrm{KH}_{2} \mathrm{PO}_{4}+1,868 \mathrm{~g} \mathrm{dm}^{-3} \mathrm{NaOH}$. The adequate volume of the chloride anions is added to the investigated solutions using different micro-burettes $(10,100$ and $5000 \mu \mathrm{l})$ from starting sodium chloride stack solutions of $15 \mathrm{~g} \mathrm{dm}^{-3}$. The corresponding sodium chloride (chloride anions) concentrations is investigated: $10(6) ; 50(30) ; 100(60)$ and $300(180)$ $\mathrm{mg} \mathrm{dm}^{-3}$. The polarization measurements at room temperature are conducted after 55 min of expose to corrosion potential, according to ASTM Designation: G 59 - 97 [10]. Optical micrographs are obtained with an optical microscope Olympus CX41 connected to the personal computer.

Table 1. The chemical composition of aluminum alloy EN 46100 [9]

Tabela 1. Hemijski sastav legure aluminijuma EN 46100 [9]

\begin{tabular}{|c|c|c|c|c|c|c|c|c|c|c|c|c|}
\hline & $\begin{array}{l}\mathrm{Al} \\
\%\end{array}$ & $\begin{array}{l}\mathrm{Si} \\
\%\end{array}$ & $\begin{array}{l}\mathrm{Cu} \\
\%\end{array}$ & $\begin{array}{c}\mathrm{Mn} \\
\%\end{array}$ & $\begin{array}{c}\mathrm{Mg} \\
\%\end{array}$ & $\begin{array}{c}\mathrm{Fe} \\
\%\end{array}$ & $\begin{array}{l}\mathrm{Ni} \\
\%\end{array}$ & $\begin{array}{c}\mathrm{Zn} \\
\%\end{array}$ & $\begin{array}{c}\mathrm{Pb} \\
\%\end{array}$ & $\begin{array}{l}\text { Sn } \\
\%\end{array}$ & $\begin{array}{l}\mathrm{Ti} \\
\%\end{array}$ & $\begin{array}{l}\mathrm{Cr} \\
\%\end{array}$ \\
\hline EN 46100 & ost. & $10-12$ & $1,5-2,5$ & 0,55 & 0,3 & $0,45-1$ & 0,55 & 1,7 & 0,25 & 0,15 & $0,2(5)$ & 0,15 \\
\hline
\end{tabular}

\section{RESULTS AND DISCUSSION}

In Fig. 1 the polarization curve of the aluminum alloy in the $\mathrm{pH}=7$ solution without the presence of chloride is shown. The value of the corrosion potential is around $-0.53 \mathrm{~V}$, with corrosion current density of $2 \times 10^{-7} \mathrm{~A} \mathrm{~cm}^{-2}$. Aluminum is practically in the passive state up to $\sim 0.3 \mathrm{~V}$, with a passive current density value of $\sim 10 \mu \mathrm{A} \mathrm{cm} \mathrm{cm}^{-2}$. In the reverse scan, the current additionally decrease, and the protective potential $\left(E_{\mathrm{rp}}\right)$ is about $-0.35 \mathrm{~V}$ [11]. We can see that the protective potential of aluminum $\left(E_{\mathrm{rp}}\right)$ in solution $\mathrm{pH}=7$ without chloride is more positive than the corrosion potential $\left(E_{\text {corr }}\right)$, which means that aluminum is protected in this case, i.e. will not succumb to the eventual pitting corrosion, due to the presence of oxygen, on the corrosion potential $[12,13]$.

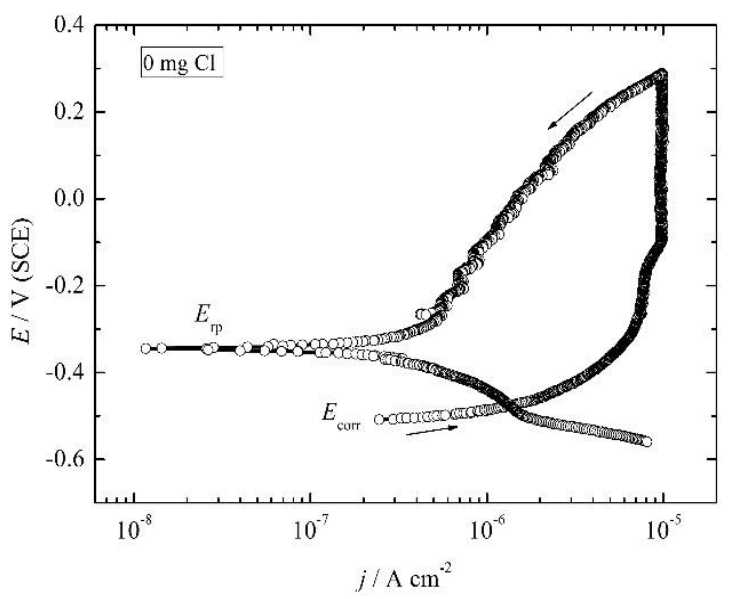

Figure 1. Polarization curve ( $v=1 \mathrm{mV} \mathrm{s}-1)$ of aluminum alloy in solution $\mathrm{pH}=7$ without the presence of chloride

Slika 1. Polarizaciona kriva $\left(v=1 \mathrm{mV} \mathrm{s}^{-1}\right)$ legure aluminijuma $\mathrm{u}$ rastvoru $\mathrm{pH}=7$ bez prisustva hlorida
Figure 2, shows the dependence of the current density on the potentials at different concentrations of sodium chloride in the range of 10 to $300 \mathrm{mg} \mathrm{dm}^{-}$ ${ }^{3}$. It can be seen that for the chloride concentrations 0 and $10 \mathrm{mg} \mathrm{dm}^{-3}$ there is practically no change in the current density (no pitting corrosion) to the potential of $\sim 0.3 \mathrm{~V}$. With a sodium chloride concentration of $50 \mathrm{mg} \mathrm{dm}^{-3}$ and more, there is a rapid increase in the current density at lower potentials, indicating a pitting corrosion. The more chloride is in the solution, the larger is the current density at lower potentials.

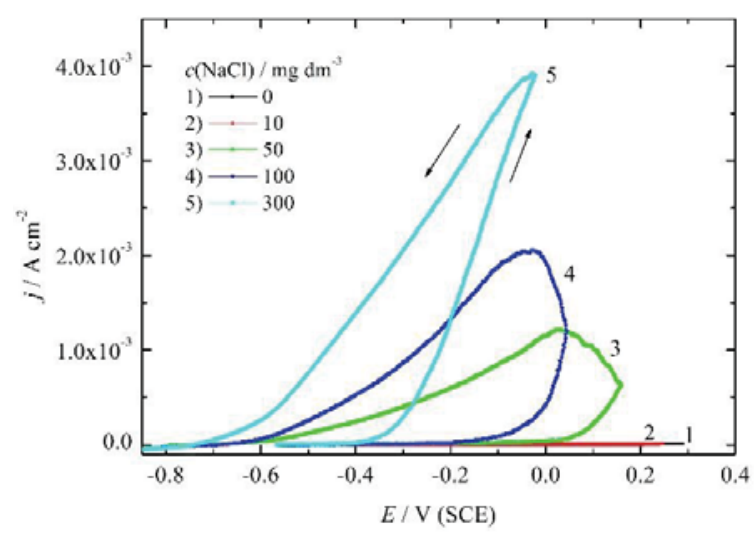

Figure 2. Polarization curve $\left(v=1 \mathrm{mV} \mathrm{s}^{-1}\right)$ of aluminum alloy in solution $\mathrm{pH}=7$ for different concentrations of sodium chloride

Slika 2. Polarizaciona kriva $\left(v=1 \mathrm{mV} \mathrm{s}^{-1}\right)$ legure aluminijuma $u$ rastvoru $\mathrm{pH}=7 \mathrm{za}$ različite koncentracije natrijum-hlorida

In order to determine the characteristic values of the aluminum alloy corrosion (indicated in the diagram) in chloride containing solutions [11], Fig. 3 shows the dependence of the potential on the logarithm of current density. 


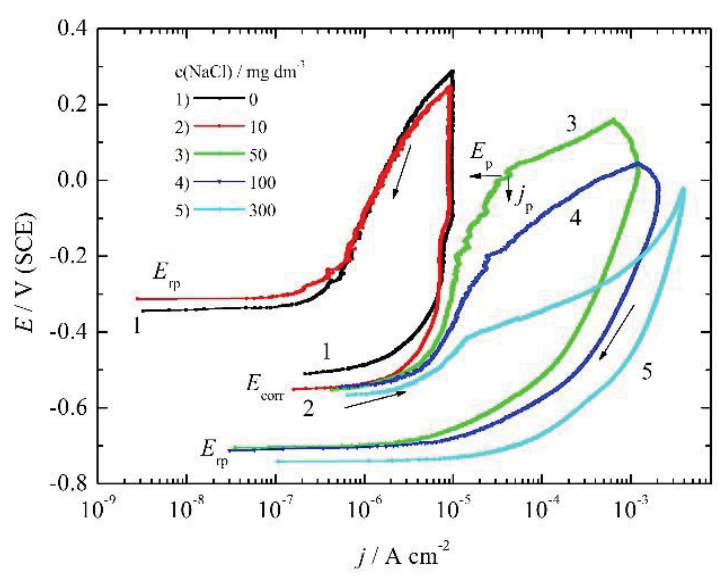

Figure 3. Polarization curve $\left(v=1 \mathrm{mV} \mathrm{s}^{-1}\right)$ of aluminum alloy in $\mathrm{pH}=7$ for different

concentrations of sodium chloride $\left(E_{\text {corr }}\right.$ corrosion potential, $E_{r p}$-potential of repassivation or protective

potential, $E_{p}$-pitting potential, $j_{p}$-pitting current density)

Slika 3. Polarizaciona kriva $\left(v=1 \mathrm{mV} \mathrm{s}^{-1}\right)$ legure aluminijuma u rastvoru $\mathrm{pH}=7$ za različite koncentracije natrijum-hlorida ( $E_{\text {corr }}$-korozioni potencijal, $E_{r p}$-potencijal repasivacije ili zaštitni potencijal)

From Fig. 3 the values of the corrosion and protection potential are determined and shown in Fig. 4. Because pitting occurs at potentials more positive than the protective potential, it can be seen that pitting corrosion, theoretically, can occur at chloride concentrations greater than $\sim 20 \mathrm{mg} \mathrm{dm}^{-3}$ (or $\sim 33 \mathrm{mg} \mathrm{dm}^{-3} \mathrm{NaCl}$ ).

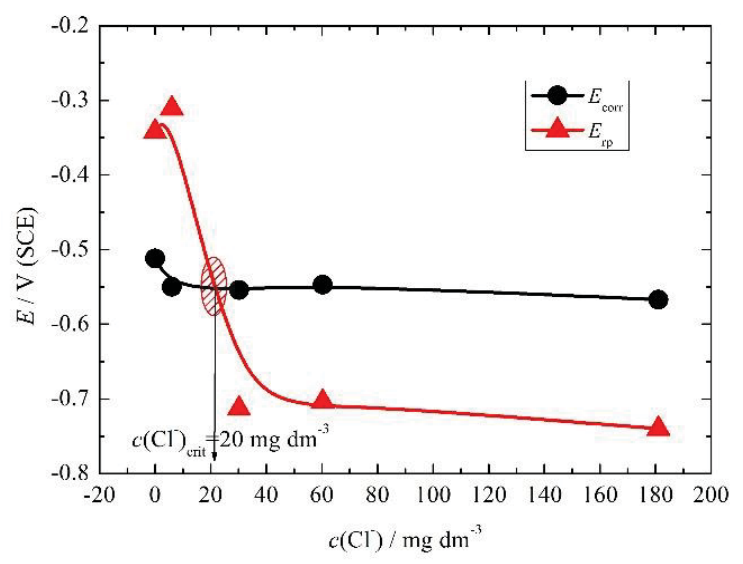

Figure 4. The determined values $E_{\text {corr-corrosion }}$ potential and $E_{r p}$-protection potential, depending on the chloride concentration of

Slika 4. Određene vrednosti $E_{\text {corr }}$-korozionog potencijala i $E_{r p}$-zaštitnog potencijala u zavisnosti od koncentracije hlorida
In Fig. 5, in order to more preciously determine the pitting potential and current density, Fig. 2 is shown for the lower values of the current densities. It can be seen that the critical pitting potentials $\left(E_{p}\right)$ are shifted to more negative potentials by the increase in chloride concentration. In addition, the critical current density decrease with increasing chloride concentration and it is only $15 \mu \mathrm{A} \mathrm{cm}{ }^{-2}$ for the sodium chloride concentration of $300 \mathrm{mg} \mathrm{dm}^{-3}$. Fig. 6 shows the characteristic values of the critical pitting potential while the pitting current densities are shown in Fig. 7. It should be mentioned that for the concentration of $10 \mathrm{mg} \mathrm{dm}^{-3} \mathrm{NaCl}$ the metastable pitting occurred up to the potentials of 1 $\checkmark$ without reaching the critical pitting potentials [14].

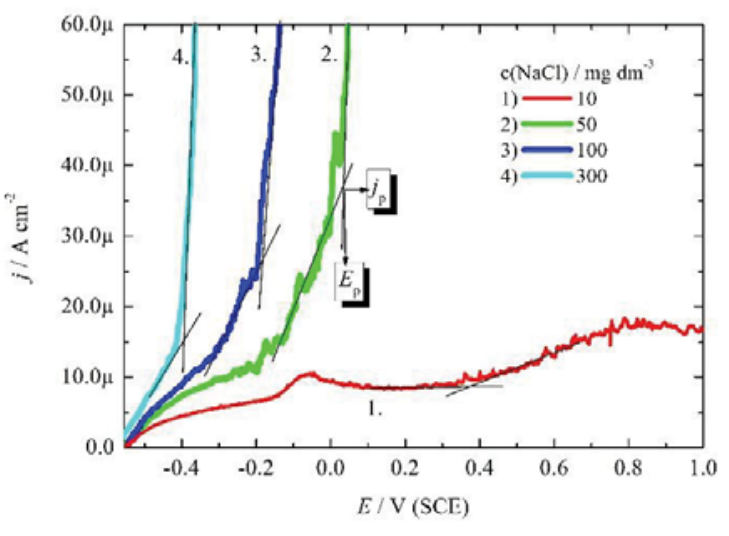

Figure 5. Determination of critical pitting potentials and current densities

Slika 5. Određivanje kritičnog piting potencijala $i$ gustine struje

Figure 6 shows the dependence of the critical pitting potentials on the concentration of chloride ions. As can be seen, there is a linear relationship between the potentials and the concentration of chloride ions:

$$
E_{p}=a+b \log c(C l)
$$

where $a$ is $0.758 \mathrm{~V}$ and $b$ is $-0.511 \mathrm{~V} \mathrm{dec}^{-1}$. Extrapolating the line to the corrosion potential ($0.55 \mathrm{~V}$ ) has shown that pitting corrosion can occur at the corrosion potential, for the chloride ions concentration of $\sim 400 \mathrm{mg}$.

For the investigated alloy, the pitting corrosion at low level of chloride anions are rarely investigated and presented in the literature. The corrosion ability of the investigated alloy can be compared with reported results for pure aluminum and some aluminum alloys. For example, for the pure aluminum the pitting potentials of $-0.61 \mathrm{~V}$ (SCE) in the solution containing $0.355 \mathrm{~g} \mathrm{dm}^{-3}$ of chloride ions is reported [15], while Lee and Pyun 
reported the pitting potentials of $-0.65 \mathrm{~V}$ (SCE) under the same conditions [16]. Mazhar et al. reported that aluminum alloy containing $11 \mathrm{wt} \%$ of $\mathrm{Si}$, undergoes to pitting corrosion at $\mathrm{pH}=7$, at potential of $-0.5 \mathrm{~V}$ for chloride ions concentration of $0.35 \mathrm{~g} \mathrm{dm}^{-3}$ and at $-0.65 \mathrm{~V}$ for chloride ion concentration of $3.55 \mathrm{~g} \mathrm{dm}^{-3}$, which is in an agreement with our results [17]. Zaid et al. [18] reported that at $\mathrm{pH}=6$, aluminum alloy $\mathrm{AA6061}$ undergoes to pitting corrosion at $-0.55 \mathrm{~V}$ (SCE) even with sodium chloride concentration of $3 \mathrm{mg}$ $\mathrm{dm}^{-3}$. Younis et al. [19] determined pitting potential of AA7075 aluminum alloy at $\mathrm{pH}=7$ in $\sim 3 \mathrm{~g} \mathrm{dm}^{-3}$ of sodium chloride to be $-0.6 \mathrm{~V}$ (SCE).

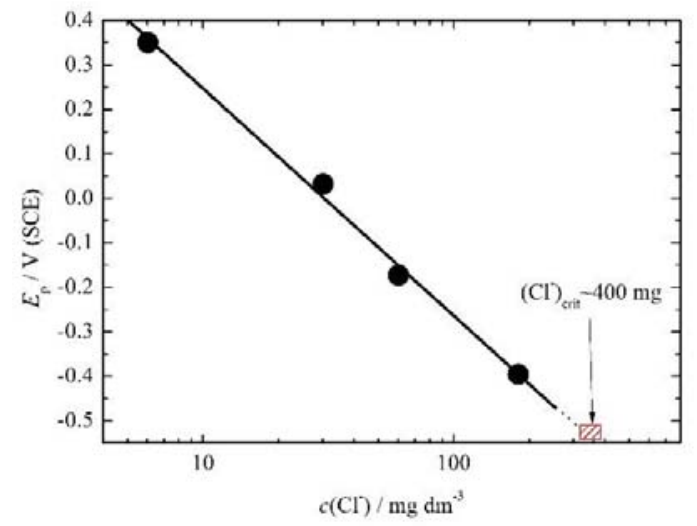

Figure 6. The dependence of critical pitting potential on the concentration of chloride ion. $(\mathrm{Cl}-$ )$_{\text {crit }}$ critical concentration of chloride ion to reach the pitting already on the corrosion potential of $\sim-0.55$

$$
\mathrm{V}
$$

Slika 6. Zavisnost kritičnog piting potencijala od koncentracije jona hlorida. $\left(\mathrm{Cl}^{-}\right)_{\text {crit }}$ kritična koncentracija jona hlorida da do pitinga dođe već na korozionom potencijalu od $\sim-0,55 \mathrm{~V}$

Figure 7 shows the dependence of the pitting current density on the concentration of chloride ion, where extrapolation also determines the critical concentration of chloride ion in which pitting will occur without the subsequent polarization of aluminum, of about 450 to $500 \mathrm{mg} \mathrm{dm}^{-3}$. The dependence of the current density on the concentration of chloride can be given as:

$$
j_{p}=a^{\prime}+b^{\prime} \log c(C l)
$$

where $a^{\prime}$ is $\sim 78 \mu \mathrm{A} \mathrm{cm}^{-2}$, and $b^{\prime}$ is $-28 \mu \mathrm{A} \mathrm{cm}{ }^{-2} \mathrm{dec}^{-1}$.

Figure 8 shows the current density dependency over time. After $200 \mathrm{~s}$ in chloride-free solution at corrosion potential, electrode is polarized anodically for $300 \mathrm{mV}$ (200-700 s) without the chloride and after the addition of $180 \mathrm{mg} \mathrm{dm}^{-3}$ of chloride. It can be seen that aluminum is up to 700 $\mathrm{s}$ in a passive state even after polarization. After adding $180 \mathrm{mg} \mathrm{dm}^{-3}$ of chloride ions, the rapid increase of the current density is observed indicating the development of the pitting corrosion.

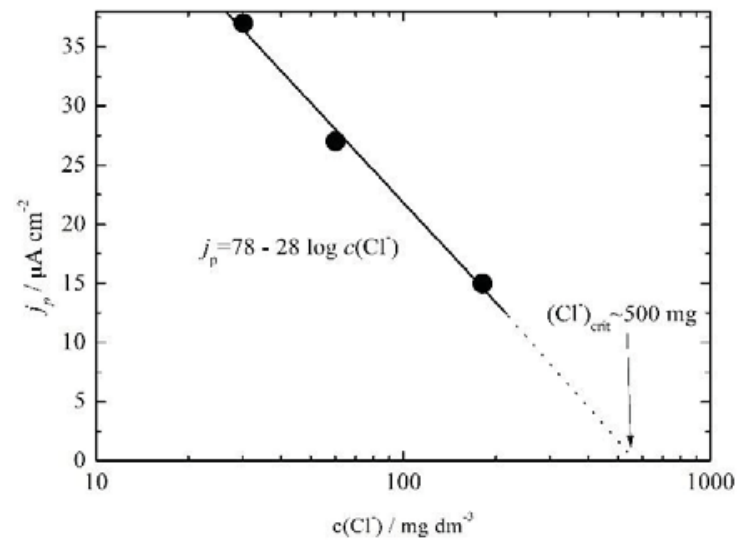

Figure 7. Dependence of the pitting current density on the concentration of chloride ion, $\left(\mathrm{Cl}^{-}\right)_{\text {crit }}$ - critical concentration of chloride ion to provoke pitting without polarization

Slika 7. Zavisnost gustine struje pitinga od koncentracije jona hlorida, $\left(\mathrm{Cl}^{-}\right)_{\text {crit }}$ kritična koncentracija jona hlorida da do pitinga dođe bez polarizacije

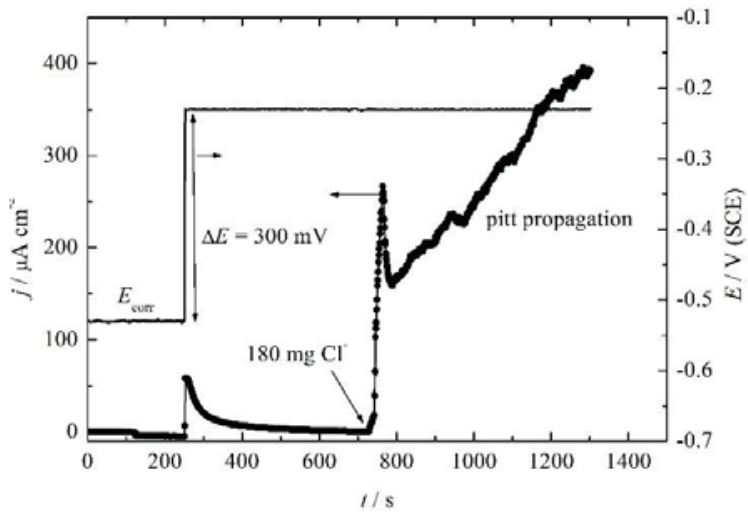

Figure 8. Dependence of the current density over $200 \mathrm{~s}$ without chloride, on the corrosion potential, after electrode polarization anodicaly for $300 \mathrm{mV}$ (200-700 s) without the presence of chloride and after the addition of $180 \mathrm{mg} \mathrm{dm}^{-3}$ of chloride

Slika 8. Zavisnost gustine struje od vremena tokom 200 s bez hlorida na korozionom potencijalu, polarizacije elektroda anodno za 300 mV (200-700 s) bez prisustva hlorida i nakon dodatka $180 \mathrm{mg}$ $d m^{-3}$ hlorida

Figure 9 shows the micrographs of the aluminum surfaces before and after the experiment shown in Figure 8. From the images developed pits, with a diameter of $\sim 100 \mu \mathrm{m}$ can be easily 
seen, even the electrode is polarized in the presence of chloride only for $600 \mathrm{~s}$.
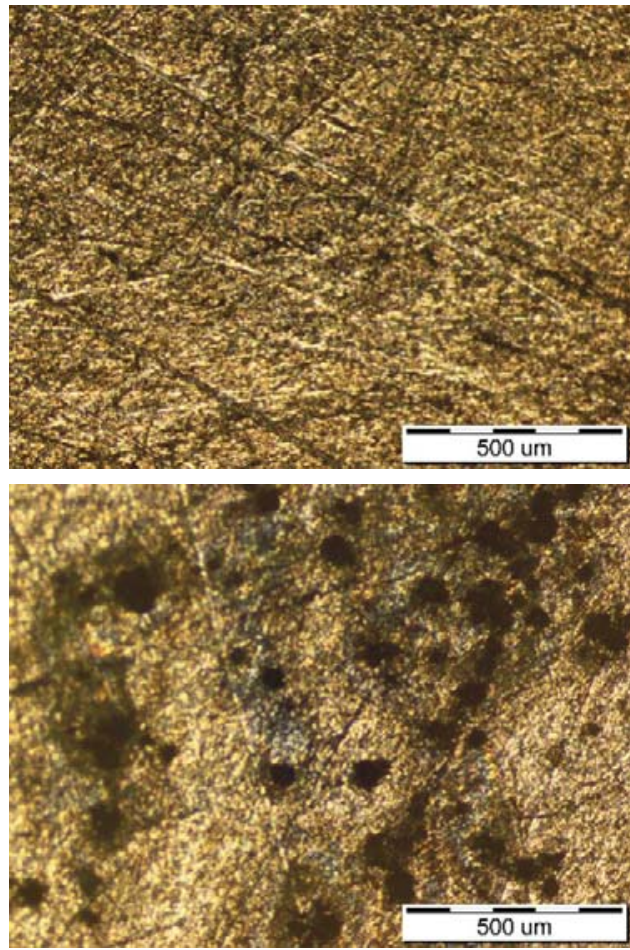

Figure 9. Micrograph images of the aluminum alloy before and after the experiment shown in Figure 8

Slika 9. Mikrografski snimci legure aluminijuma pre i posle eksperimenta prikazanog na slici 8

In order to investigate the possibility of pitting corrosion of aluminum alloy in contact with copper, the following experiments are performed and shown in Fig. 10. Aluminum alloy is after reaching the stable corrosion potential of $-0.55 \mathrm{~V}$ connected with a copper plate $\left(E_{\text {corr }}=-0.02 \mathrm{~V}\right)$ with the same surface area. After connection, the potential of the aluminum is very fast shifted to the more positive potentials of $\sim-0.15 \mathrm{~V}$. At the same time current density after an initial jump to $\sim 20 \mu \mathrm{A} \mathrm{cm}{ }^{-2}$, slowly decrease to very small values. After adding $30 \mathrm{mg}$ $\mathrm{dm}^{-3}$ of chloride, potentials rapidly fall down almost to the corrosion potential followed by the rapid current increase. However, very fast, the repassivation of the surface occurred and only metastable pitting can be observed. On the other hand, the addition of the total chloride concentrations of $180 \mathrm{mg} \mathrm{dm}^{-3}$, provoke the decrease of the potential to $\sim-0.4 \mathrm{~V}$, which corresponds to the critical pitting potential, see Fig. 5 , with a stable pitting current density of $\sim 15 \mu \mathrm{A}$ $\mathrm{cm}^{-2}$. Hereafter, with this simple experiment, is shown that aluminum alloy can undergo to pitting corrosion in contact with copper at the concentration of chloride $180 \mathrm{mg} \mathrm{dm}^{-3}$, which is smaller than maximally allowed of $300 \mathrm{mg} \mathrm{dm}^{-3}$ [8].

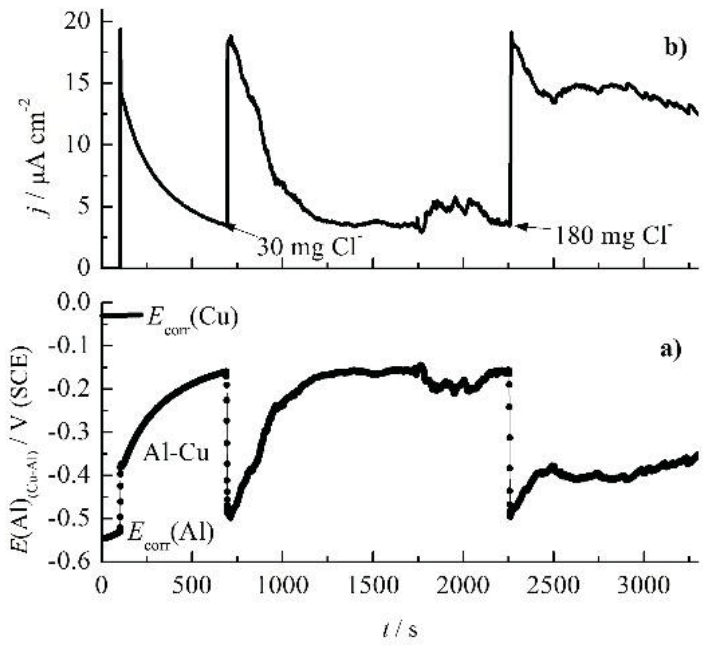

Figure 10. a) The time dependence of the polarization of the aluminum alloy electrode in connection with the copper of an equal surface area without and with the addition of 30 and 180 $\mathrm{mg} \mathrm{dm}$ of chloride. b) The time dependence of the corrosion current of the copper-aluminum cell.

Slika 10. a) Vremenska zavisnost potencijala legure aluminijuma tokom polarizacija elektrode od legure aluminijuma u spregu sa bakrom jednake površine bez i sa dodatkom 30 i $180 \mathrm{mg} \mathrm{dm}^{-3}$ hlorida. b) Zavisnost korozione struje od vremena sprega aluminijum bakar.

\section{CONCLUSIONS}

Based on the obtained results, it can be concluded that the critical concentration of chloride ions, which is theoretically necessary to induce a pitting corrosion of aluminum alloy, is $\sim 20 \mathrm{mg} \mathrm{dm}$ ${ }^{3}$. If not polarized, pitting corrosion of the aluminum alloy will certainly start at the corrosion potential if the concentration of chloride ions is $\sim 400-500 \mathrm{mg}$ $\mathrm{dm}^{-3}$. Under the anodic polarization, for example in contact with copper, it is possible that pitting corrosion starts at the chloride ions concentration of $\sim 180 \mathrm{mg} \mathrm{dm}^{-3}$.

\section{Acknowledgement}

The research was supported by the Ministry of Education, Science and Technological Development of the Republic of Serbia, under the research project "Electrochemical synthesis and characterization of nanostructured functional materials for applications in new technologies" No. ON172046.

\section{REFERENCES}

[1] M. Merlin (2008) Correlation between microstructural and mechanical properties of aluminum alloy casting produced by different foundry processes, Doctoral dissertation, University of Ferrara, Italy. 
[2] Hirth, S. M., G. J. Marshall, S.A Court, D.J Lloyd (2001) Effects of Si on the aging behaviour and formability of aluminium alloys based on AA6016, Mat. Sci. Eng. A, 319-321, 452-456.

[3] S. J. García, T. H. Muster, Ö. Özkanat, N. Sherman, A.E. Hughes, H. Terryn, J.H.W. de Wit, J.M.C. Mo (2010) The influence of $\mathrm{pH}$ on corrosion inhibitor selection for 2024-T3 aluminium alloy assessed by high-throughput multielectrode and potentiodynamic testing, Electrochim. Acta, 55(7), 2457-2465.

[4] N.Birbilis, T. Muster, R.G. Buchheit (2011) Corrosion of aluminum alloys. Corrosion mechanisms in theory and practice, Third Edition, CRC Press, p. 705-736.

[5] N. L. Sukiman, X. Zhou, N. Birbilis, A.E. Hughes, J. M. C. Mol, S. J. Garcia, X. Zhou and G. E. Thompson (2012) Durability and corrosion of aluminium and its alloys: Overview, property space, techniques and developments, Aluminium alloys new trends in fabrication and applications, Z. Ahmad (Ed.), InTech, DOI: 10.5772/53752.

[6] F. Eckermann, T. Suter, P.J. Uggowitzer, A. Afseth, P. Schmutz. (2008) The influence of MgSi particle reactivity and dissolution processes on corrosion in Al-Mg-Si alloys, Electrochim. Acta, 54(2), 844-855.

[7] R.K. Gupta, N. L. Sukiman, , M.K. Cavanaugh, B.R.W. Hinton, C.R. Hutchinson, N. Birbilis (2012) Metastable pitting characteristics of aluminium alloys measured using current transients during potentiostatic polarisation, Electrochim. Acta, 66, 245-254.

[8] Lj.V. Rajaković (2007) Korozijski procesi u termoenergetskim postrojenjima usled neadekvatnog kvaliteta vode, Integritet i vek konstrukcija, 7(2), 8388.

[9] European Standard EN 1706: 1997 Aluminum and aluminum alloys - Castings, Chemical composition and mechanical properties.
[10] ASTM Designation: G 59 - 97 (Reapproved 2003) Standard Test Method for Conducting Potentiodynamic Polarization Resistance Measurements.

[11] I. M. Comotti, M. Trueba, S. P. Trasatti (2013) The pit transition potential in the repassivation of aluminium alloys, Surf. Interface Anal., 45, 15751584.

[12] G. S. Frankel (1998) Pitting corrosion of metals: A review of the critical factors, J. Electrochem. Soc., 145(6), 2186-2198.

[13] P.M. Natishana, W. E. O'Grady (2014) Chloride ion interactions with oxide-covered aluminum leading to pitting corrosion: A Review, J. Electrochem. Soc., 161 (9), C421-C432.

[14] Y. Tang, Yu Zuo, J. Wang, X. Zhao, B. Niu, B. Lin (2014) The metastable pitting potential and its relation to the pitting potential for four materials in chloride solutions, Corr. Sci., 80, 111-119.

[15] E. McCafferty (1995) The electrode kinetics of pit initiation on aluminum, Corros. Sci., 37, 481-489.

[16] 16. W-J. Lee, S-I. Pyun (1999) Effects of hydroxide ion addition on anodic dissolution of pure aluminium in chloride ion-containing solution, Electrochim. Acta., 44, 4041-4049.

[17] A.A. Mazhar, S.T. Arab, E.A. Noor (2001) The role of chloride ions and $\mathrm{pH}$ in the corrosion and pitting of Al-Si alloys, E. J. Appl. Electrochem., 31, 11311140.

[18] B. Zaid, D. Saidi, A. Benzaid, S. Hadji (2008) Effects of $\mathrm{pH}$ and chloride concentration on pitting corrosion of AA6061 aluminum alloy, Corr. Sci., 50, 1841-1847.

[19] A. A. Younis, M.M. B. El-Sabbah, R. Holze (2012) The effect of chloride concentration and $\mathrm{pH}$ on pitting corrosion of AA7075 aluminum alloy coated with phenyltrimethoxysilane, J. Solid State Electrochem., 16,1033-1040

\title{
IZVOD
}

\section{UTICAJ HLORIDNIH ANJONA NA TAČKASTU KOROZIJU LEGURE ALUMINIJUMA EN 46000}

\begin{abstract}
Ispitano je korozivno ponašanje aluminijumske legure AISi9Cu3, koje se obično koristi za proizvodnju radijatora u sistema daljinskog centralnog grejanja. $U$ fosfatnom puferskom rastvoru pri $\mathrm{pH}=7$, u opsegu koncentracije natrijum hlorida $10-300 \mathrm{mg} \mathrm{dm_{-3 }}$ ispitivana je tendencija ka tačkastoj korozije. Procenjeni su kritični potencijali pri kojima može doći do tačkaste korozije. Ispitano je i ponašanje aluminijumske legure i bakarnog korozionog sprega.

Ključne reči: korozija, sistemi centralnog grejanja, radijatori, kritični potencijal.
\end{abstract}

Naučni rad

Rad primljen: 19. 03. 2018.

Rad prihvaćen: 24. 04. 2018.

Rad je dostupan na sajtu: www.idk.org.rs/casopis

(c) 2018 Authors. Published by Engineering Society for Corrosion. This article is an open access article distributed under the terms and conditions of the Creative Commons Attribution 4.0 International license (https://creativecommons.org/licenses/by/4.0/) 